\title{
Art Patronage, Promotion, and Publication in Nigeria: A Focus on Omooba Yemisi Adedoyin Shyllon Art Foundation (OYASAF)
}

\author{
Tobenna Okwuosa \\ Department of Fine and Applied Arts, Niger Delta University, Nigeria.
}

\begin{abstract}
The modern/contemporary art scene in Nigeria has been experiencing significant growth in local patronage, promotion, research, and publication. However, there has been a shift in the trend that prevailed until the early 1980s, when the majority of buyers and patrons were expatriates--mostly Europeans and Americans, rather than Nigerians. Among the new tribe of local collectors and patrons, Prince (Engr.) Omooba Yemisi Adedoyin Shyllon is widely believed to have the largest collection of Nigerian artworks. In 2007, his activities in the art world were formally institutionalized with the founding of Omooba Yemisi Adedoyin Shyllon Art Foundation (OYASAF), a non-profit and self funded foundation with strong commitment in the areas of art collecting, research, promotion, and documentation of indigenous cultural festivals/practices. Furthermore, OYASAF has been mediating opportunities for exchanges in the arts by bringing to Nigeria: art scholars, critics, and graduate students from the outside. This paper maps the foundation's trajectory in its art, cultural, social, academic, and philanthropic commitments.
\end{abstract}

Keywords: art patronage, art promotion, neo-traditional art, traditional art, Nigerian modernism

\section{Introduction}

The contemporary art scene in Nigeria has been experiencing significant growth in patronage, promotion, research, and publication in the recent times. However, there has been a shift in the trend that prevailed until the early 1980s, when the majority of buyers and patrons were expatriates--mostly Europeans and Americans, rather than Nigerians. Early Nigerian modernism was largely influenced, patronized, promoted and theorized by Western and expatriate art practitioners, patrons, brokers, scholars and teachers. The example of Kenneth C. Murray, the first expatriate art teacher in Nigeria, in mentoring and promoting the works of his students is a case in point. Murray showed the works of his pioneer students, Ben Enwonwu being the most significant, in a Lagos show followed by a London exhibition at the Zwemmer Gallery in 1937 and the Empire Exhibition in 1938 in Glasgow. ${ }^{1}$ These activities garnered some institutional and individual patronage for early modern Nigerian art. Ulli Beier, Georgina Beier and Susanne Wenger were major patrons who came to the fore in the 1960s and 70s. Their activities developed and promoted the perceived unsullied creative talents of indigenes who were considered uncontaminated by Western art academicism and formalism. These expatriate patrons, collectors and brokers were responsible for the emergence of the Oshogbo group whose works were valorized and promoted on the global art stage as the authentic modern and contemporary Nigerian art. This primitivist project and the Western construct of authenticity in the visual arts, disadvantaged the early modernists--who were formally trained in Western art schools and institutions.

The development of a strong indigenous market for modern art did not happen in Nigeria at Independence. It did not occur until the 1980s. Prior to this period, very few Nigerians were committed to the promotion of contemporary Nigerian art through active patronage and support. Christopher Nnonyelum Okeke who sponsored the publication of Contemporary Textures: Multidimensionality in Nigerian Art (1999) edited by Nkiru Nzegwu noted in his Foreword the commitment of late Babs William to promoting contemporary Nigerian art: "Sometime in the late seventies, William had spoken passionately to a group of young Nigerian professionals about the importance of collecting works of art. Never tiring of championing the arts, he pointed out that it was through collecting and supporting the art, that we more fully understand the times we live in, and ultimately fashion our cultural identity." ${ }^{2}$ Finally, in the mid-1980s, the Nigerian art market experienced a sudden upsurge in patronage by indigenous collectors. This art boom followed the emergence of several "Nigerian-owned Merchant Banks, Credit and Finance Companies, and Bureaux du [sic] Change. Between 1987 and 1993 phenomenal profits were reaped by these financial bazaars simply by selling off their foreign exchange quota allocations." ${ }^{3}$ This situation was augmented and complicated by the emergence of the first set of 419 (scammers) millionaires. With so much easy and free money in circulation, art collecting and patronage become a status-oriented activity for some collectors and patrons. H. C. Ngumah notes that, "During the era or peak period of "419" (that is, superlative fraud) in Nigeria in the 1980s and early 1990s, many artists, especially sculptors, were well patronized by the money barons." ${ }^{4}$ And Nkiru Nzegwu points out that, "in this frenetic, volatile environment, 'sold out' became the code-word for successful exhibitions, and depending on what works 
sold, artistic styles switched erratically from uli, wet-on-wet, found-metal sculpture, and more." ${ }^{5}$ All of these were unfolding under the regime of General Ibrahim Badamosi Babangida who came to power through an army coup in 1985 and turned Nigeria into what some refer to as a "419 country." This moment of boom in art patronage was quickly replaced by a decline as the burden of the Structural Adjustment Programmes (SAP) introduced under the dictatorship of General Babangida began to take effect. Although most of the vainglorious collectors that emerged in this period have shifted their interest away from art, indigenous collectors and patrons have continued to dominate the scene. Also recently, there has been an upsurge in homegrown publications on contemporary Nigerian art, artists, and the market. This essay focuses on an indigenous foundation: the Omooba Yemisi Adedoyin Shyllon Art Foundation (OYASAF), a nonprofit and self-funded organization with a strong commitment in the areas of art collecting, promotion, research, publication and documentation of indigenous cultural festivals and practices.

\section{Oyasaf: Art Patronage And Collection}

The Omooba Yemisi Adedoyin Shyllon Art Foundation (OYASAF) was founded in 2007, but the major activities--art patronage, collection, and promotion--on which the Foundation is built have been in place since 1975. This was the year the founder Prince (Engr.) Omooba Yemisi Adedoyin Shyllon started collecting art. He was then a second year engineering student at the University of Ibadan. The first works he collected were figural carvings in wood that show evidence of the modernist abstraction (Figs. 1-2). In (Fig. 1), the artist shows a graceful female body whose rounded forms appear delicate in their smoothness. Representing a modern woman, the figure radically subverts her traditional role by standing on an upturned mortar, a symbol of womanhood and her role as a housewife in the traditional African context. The cubistic and angular forms of the (Fig. 2) suggest a male drummer in a lyrical contrapposto position. Modern and contemporary Nigerian artists have continued to find the subject matters of traditional musicians very interesting, making such themes among the most common.

Starting with these two sculptures collected in 1975 , the Foundation presently holds more than 7,000 works of art and over 55,000 photographs in its digital archive that focus on several Nigerian and Benin Republic cultural festivals. This number makes the Foundation the largest private collection of art in Nigeria. The Foundation's art collection ranges from the traditional and neo-traditional to modern and contemporary. Many significant works can be found in the collection and they eloquently speak of a rich and deep Nigerian culture and history. These artworks were acquired through commissions and purchases from artists, expatriates and indigenous collectors, dealers, commercial galleries and auction houses.

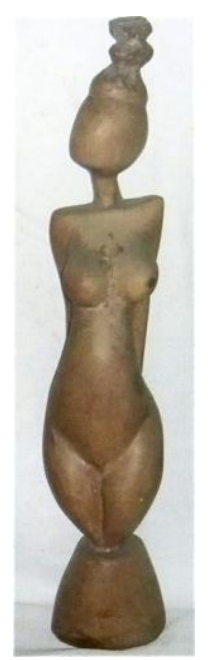

Figure 1. Anonymous, Modern Woman, n.d. ca. $1974-75$. Wood, $75 \mathrm{~cm}$. Photo: Courtesy of OYASAF

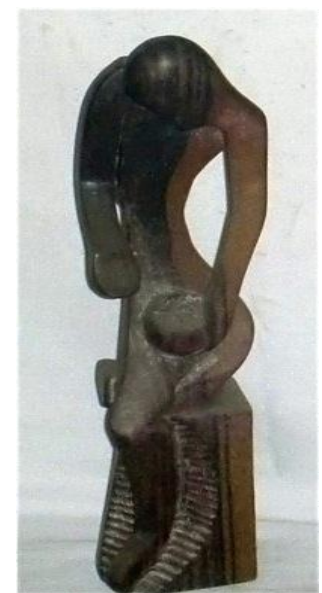

Figure 1. Anonymous, Drummer, n.d. ca. $1974-75$. Wood, $79 \mathrm{~cm}$. Photo: Courtesy of OYASAF 


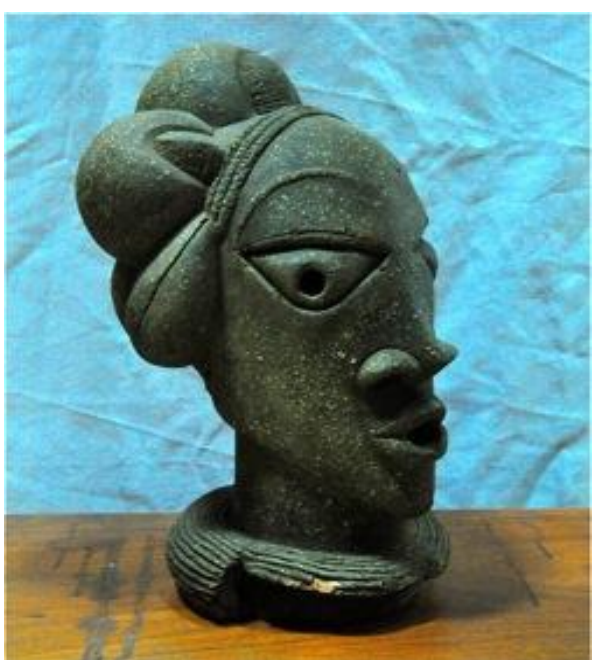

Figure 3. Nok Head, Terracotta, $27 \mathrm{~cm}$

Photo: Tobenna Okwuosa

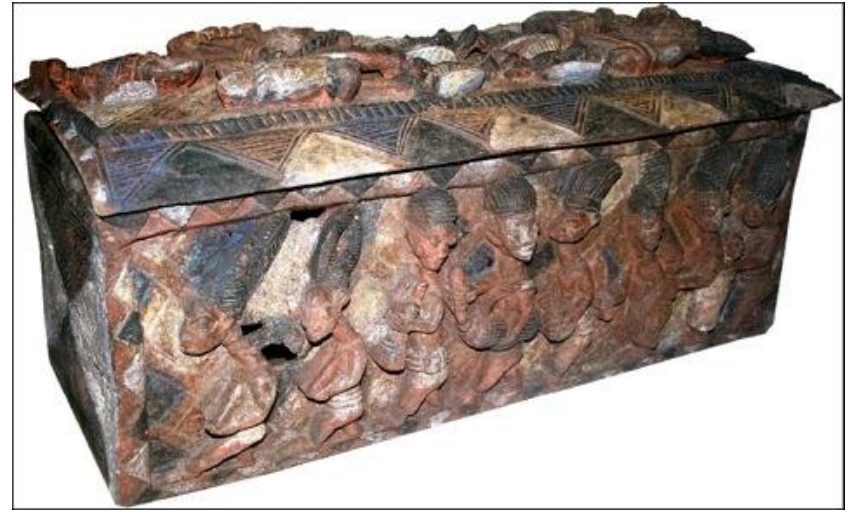

Figure 4. Yoruba Ceremonial Box by Olowe of Ise. Wood, pigment, $30 \mathrm{~cm} \times 85 \mathrm{~cm}$.

Provenance: Adesina Ogunde c. 1942 to 2006 Photo: Courtesy of OYASAF

The oldest artwork represented in the Foundation's collection is a terracotta (Fig. 3) in the style of a wellknown artifact published by Ekpo Eyo in 2000 Years of Nigerian Art (1977). It features Nok style characteristics: triangular eyes with pierced pupils, nostrils and lips. Its complex and bulbous hairstyle is enhanced with three strings of beads and a large neck ornament (a part of which has cracked off) forms the base. It references the oldest sculptural tradition in sub-Saharan Africa. ${ }^{6}$ Another significant traditional piece in the Foundation's collection is a Yoruba ceremonial box in the style of Olowe of Ise (c. 1875 - c.1938) (Fig. 4). Olowe is considered "the most important Yoruba artist of the 20th century"7; and Frank Willet in his seminal book African Art describes him as "the greatest Yoruba virtuoso sculptor." ${ }^{8}$ The intricate and complex composition of many figures, forms and designs characterizes Olowe's work. The box has many figures that include young girls, women carrying children on their backs and musicians. Similarities between this piece and Olowe's palace door in the collection of the National Museum of African Art, Washington, D.C. include the postures and gestures of a number of figures. Olowe was a renowned sculptor who worked for many kings in the Ekiti region of Yorubaland. His craftsmanship was acclaimed in the West when his work was included in the 1924 British Empire Exhibition in London.

There are many other interesting Nigerian works in OYASAF's collection representing known types. Without serious comparative study or context documentation, many of these works (as well as many works in Western collections) remain in limbo with regard to an assessment of their quality and authenticity. Sylvester Okwunodu Ogbechie has argued that the practice of using indigenous African artworks in Western collections as standards in the definition of authenticity has denied validity to works owned by African collectors, and he attributes this in part to "[t]he relative lack of publications focusing on African art [which] limits our understanding of how Africans engage their own historical legacy of indigenous art and culture in the contemporary era." ${ }^{\prime 9}$ Furthermore, he emphasizes "the need to develop a methodology for engaging Africanowned collections that allows us to distinguish between genuine cultural objects that can be documented for further scholarship, and the plethora of contemporary reproductions of canonical African art that constitute basic items of a vast trade in replicas." 10 This problem is not limited to works held by African collectors, but to works held in many collections throughout the world today.

The strength of the Foundation's collection appears to be more in neo-traditional, modern, and contemporary Nigerian art. These types of artworks dominate in their number and variety. OYASAF's collection is so wide and deep that one could easily construct a detailed narrative of Nigeria's precolonial, colonial, and postcolonial histories. Chika Okeke-Agulu has observed that "early African modernist art and visual culture presents considerable research possibilities and revelatory sources for mapping the art history of twentieth century Africa." 11 In the following paragraphs, I will discuss some of the works by early Nigerian modernists and independence artists in OYASAF's collection, with a view of highlighting aspects of our history and some critical issues in Nigerian modernism. 


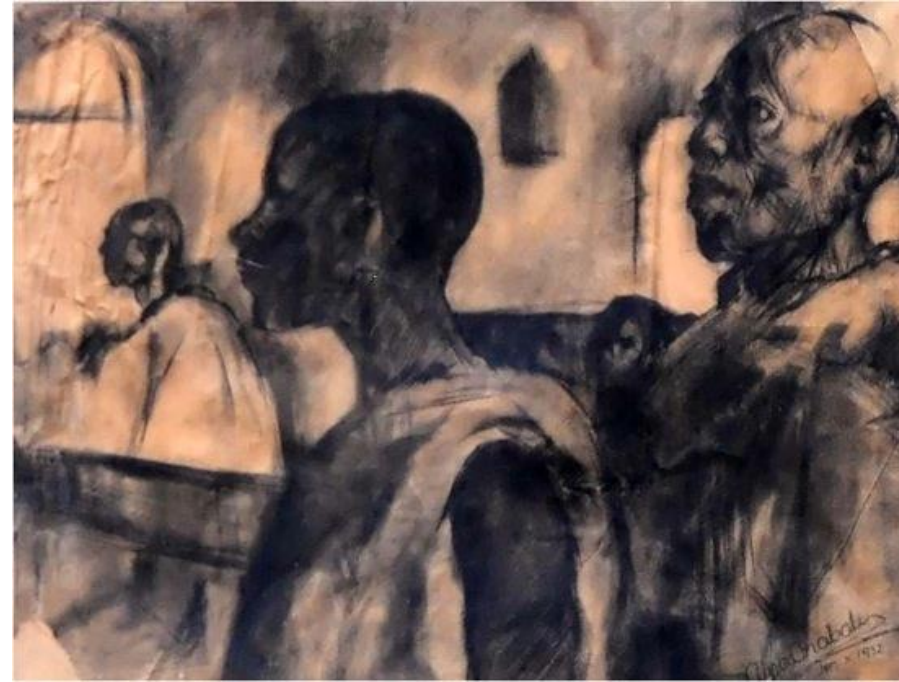

Figure 5. Aina Onabolu, Awaiting Verdict, 1932. Charcoal, 60cm x 75cm. Photo: Courtesy of OYASAF

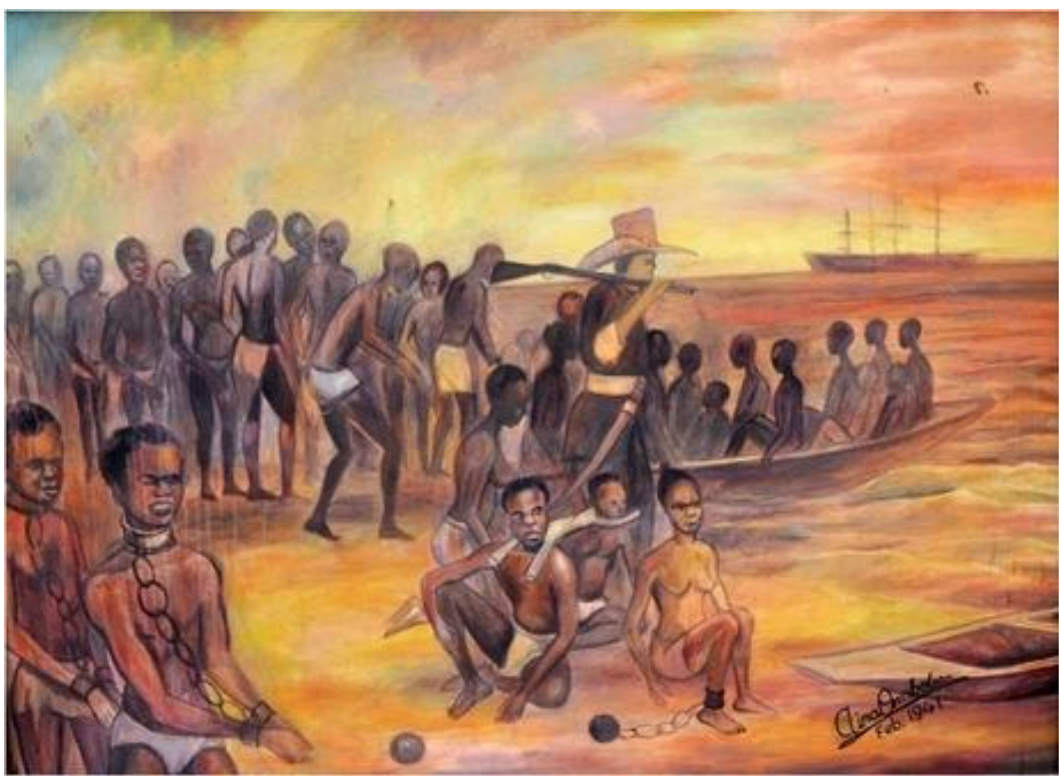

Figure 6. Aina Onabolu, Slave Trade, 1941. Oil on canvas, $99 \mathrm{~cm}$ x $129 \mathrm{~cm}$. Photo: Courtesy of OYASAF

The oldest modern work in the Foundation's collection is a 1932 drawing (Fig. 5) by Aina Onabolu (1882-1963), generally considered the father of modern Nigerian art. Onabolu was the first academically trained Nigerian artist. He studied at St. John's Wood School of Art, London, in 1922. He also played a pioneering role in the introduction of art in the secondary school curriculum. This piece attests to his mastery of the Western academic mode of realism which he used effectively in expressing African historic events. In the charcoal drawing, Onabolu combined hatching and crosshatching shading with a smudging technique that gives the work an overwhelming sfumato effect. An important historical painting by Onabolu in the Foundation is a 1941 work titled Slave Trade (Fig. 6). This is a visual account of the transatlantic slave trade that began in Africa in the sixteenth century and flourished for many years until its abolition in 1807. Lagos, the city that Onabolu lived in, was a major port where slave trafficking persisted for more than a century after it was officially abolished. ${ }^{12}$ The shoreline in this painting is crowded with slaves in shackles being conveyed in small boats to a ship on the high sea shown on the horizon. The European slave merchant stands domineeringly in their midst with a long gun on his shoulder and a sheathed sword fastened at his waist. The predominance of warm colors in this composition conveys the agony of the captives who are about to embark on a forced journey of no return. An early African modernist's visual document such as this is a rare treasure. This piece was retouched by Oyerinde Olotu in 2010 . 


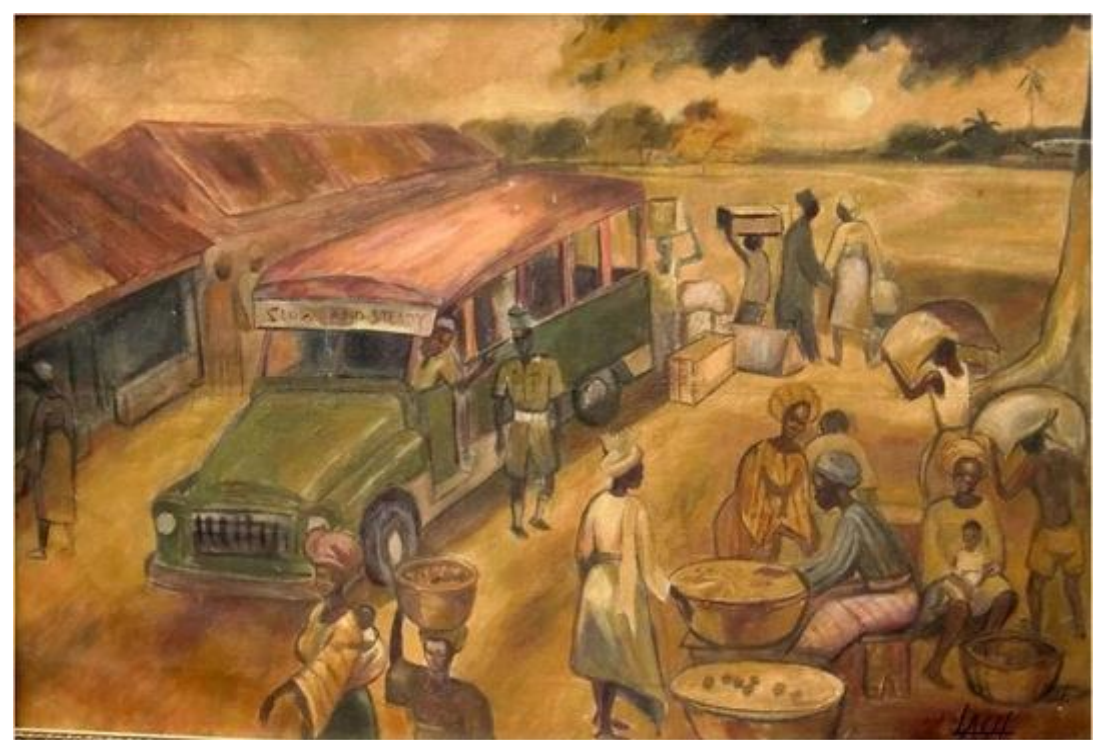

Figure 7. Akinola Lasekan, Village Market and Motor Park, 1941 . Oil on canvas, $65 \mathrm{~cm}$ x $75 \mathrm{~cm}$. Photo: Courtesy of OYASAF

Another early Nigerian modernist artist whose works are included in the Foundation's collection is Akinola Lasekan (1916-1972). Lasekan was Nigeria's first newspaper cartoonist whose political cartoons featured regularly in the West African Pilot, a newspaper founded by Nnamdi Azikiwe in 1930. Lasekan's oil painting Village Market and Motor Park, 1941 (Fig. 7) shows a village scene during the colonial period. The once Arcadian village shows influences of Western modernity that will "slowly and steadily" transform the society to the internationalized, hyper-consumerist society of today's Nigeria. The inscription above the lorry's windscreen "slow and steady," aside from its direct meaning of "consistency in slow motion," becomes a metaphoric prophecy of the gradual but radical change that followed.

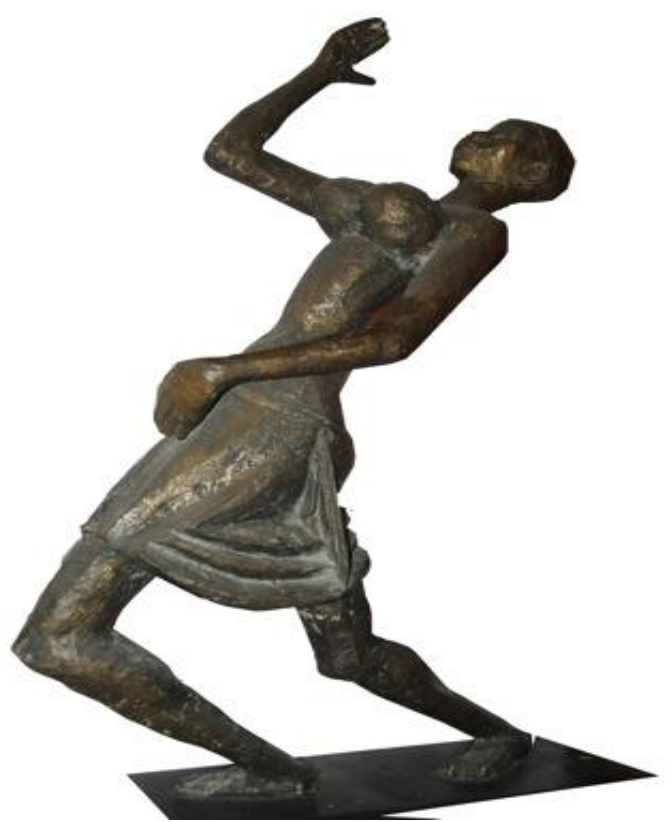

Figure 8. Ben Enwonwu, Ogolo Dancer, 1959. Bronze, $132 \mathrm{~cm}$ x $75 \mathrm{~cm}$ x 30cm. Photo: Courtesy of OYASAF

Amongst the artworks by Ben Enwonwu (1917-1994) in the Foundation's collection, the Ogolo Dancer, 1959 (Fig. 8) appears to represent Enwonwu's engagement with the philosophy of negritude that was popular in the late colonial and early postcolonial periods. With a firm body and breasts, somewhat schematized in their realism, the dancer flaunts the beauty of the black body. Besides referring to "negritude," the energetic dance may be seen as a metaphor for the nationalistic optimism that prevailed in the late colonial and early independence period. This work was produced a year after the publication of Chinua Achebe's classic Things 
Fall Apart that tells the African's story of self-assertion and cultural struggle in the face of Western acculturation and influence. Sylvester Okwunodu Ogbechie notes that "Ogolo represents the masculine aspect of the Mmonwu pantheon, and it specifically celebrates the beauty of male virility." 13 Why Enwonwu chose to call the figure of a nude female dancer after a male masquerade figure raises interesting questions, but ones beyond the scope of this paper. Ogolo is one of two Igbo masquerades, the other called Agbogho mmuo, that were important subjects explored by Enwonwu throughout his career. In some cases, the artist used aspects of these masquerades as metaphors as he appears to have done in this piece.

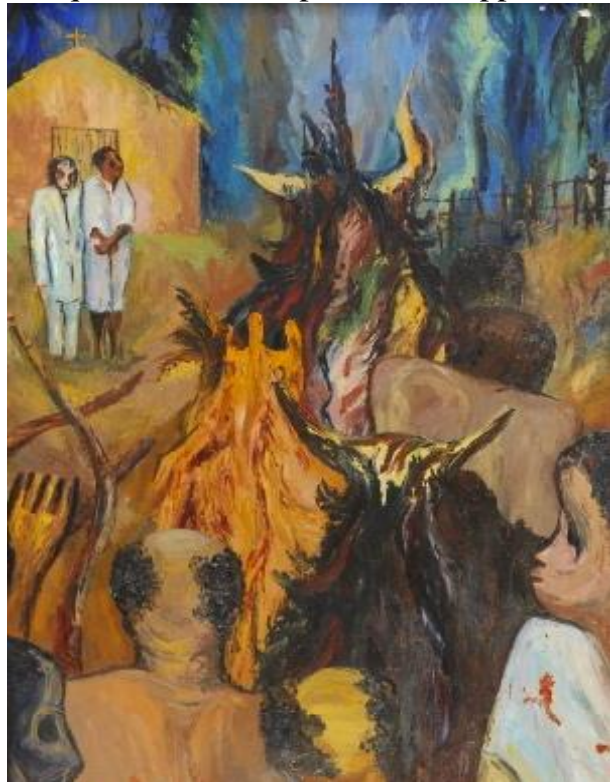

Figure 9. Uche Okeke, The Missionary and the Masquerades, 1965. Oil on hardboard, $134 \mathrm{~cm} \times 103 \mathrm{~cm}$. Photo: Courtesy of OYASAF

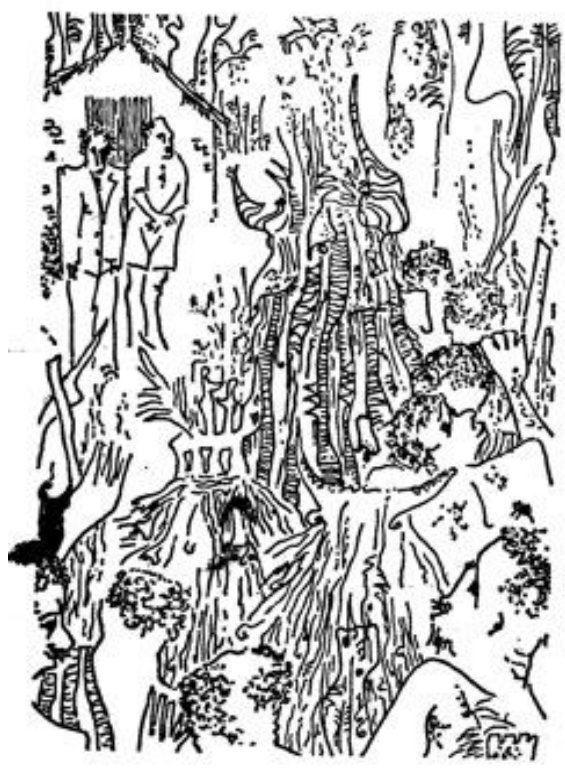

Figure 10. Uche Okeke, An illustration of The Missionary and the Masquerades, in Things Fall Apart (1965 edition).

Uche Okeke's work titled The Missionary and the Masquerades, 1965 (Fig. 9) is an oil painting based on one of his illustrations (Fig. 10) from Things Fall Apart. Here, Ajofia the leader of egwugwu (the council of masquerade judges) in Umofia addresses Mr Smith, the European missionary who is seen standing with his interpreter between the church and the rampaging masqueraders. The performers have been enraged by the unmasking of one of their kind in public by Enoch, a zealot and new convert to Christianity. Achebe writes, "The band of egwugwu moved like a furious whirlwind to Enoch's compound and with matchet and fire reduced it to a desolate heap. And from there they made for the church, intoxicated with destruction.... When the egwugwu went away the red-earth church which Mr Brown had built was a pile of earth and ashes." ${ }^{\text {"T }}$ This scene represents early resistance against Western cultural hegemony.

As a student, Okeke was one of the members of the Zaria Art Society who sought to develop a more authentic modern Nigerian art based on the strategy and philosophy of Natural Synthesis that opposed the conventional Western academic style and subject matter. Okeke explored the indigenous uli body and wall paintings as primary elements in his alternative modernism. And at this period of his artistic evolution, his knowledge of Igbo culture was deepened by Things Fall Apart. ${ }^{15}$

Abayomi Barber's works in the Foundation counter Okeke's notion of authentic modern Nigerian art. Examples of those works are Ali Maigoro ,1961 (Fig. 11) and In the Wilderness at Night, 1964 (Fig. 12). In these and other works, Barber explored with great passion the realism that characterizes the Western academy. Barber also invokes a surrealistic idiom in his paintings, garnering a good following and patronage over the years, mostly local. His art belongs to an alternative modernism that most Western critics and scholars have not given space in their African art historical narratives, believing them to be mere parodies of Western art, and so inauthentic. These Western art promoters and critics would rather valorize the artisanal realism of a Sunday Jack Akpan than the academic realism of a Barber. Barber himself vehemently objected to the notion of naïveté and doodling as the determining factors for authenticity in contemporary Nigerian art.

When Abayomi arrived in Nigeria in 1971, the state of art in contemporary Nigeria was quite disagreeable to him. His disaffection was towards the combination of primitivism and expressionism that dominated the Nigerian art scene at that time. Abayomi's criticism of primitivism in contemporary African 
art was directed at all categories of artists, not only those who had little or no training before getting into artistic production.

Moreover, he expressed his concern about the extent of damage this artistic "misrepresentation" and "falsehood" might have done to Africa in terms of reinforcing stereotypes. As a result, Abayomi has nurtured an artistic style aimed at correcting these impressions. ${ }^{16}$

Abayomi Barber was born in 1928 in Ile-Ife and was raised in the palace of the Oni of Ife where he saw classical, realistic bronzes and terracottas. ${ }^{17}$ Although Barber's realism was nurtured predominantly by Western art and his training in Europe, his style has a historical antecedent in ancient Ife sculptures and should not be described as inauthentic or as a parody of Western style.

Realistic and representational artworks have continued to receive sufficient patronage from indigenous collectors, like Yemisi Shyllon, who prioritize draftsmanship over naivete or avant-gardism. Though the artworks in OYASAF's collection cover a wide range of styles and media, they do not include conceptual or installation art like works by Dilomprizulike "The Junkman from Afrika" or Bright Ugochukwu Ekeh. The Foundation does hold a significant number of early and later works in wood by El Anatsui, the most acclaimed African artist at the moment. Two of Anatsui's works: Wisdom, 1974 (Fig. 13) and Yaw Berko (Stand Up and Shout No), 1973 (Fig. 14), in OYASAF's collection were loaned to the Museum for Africa Art, New York, for the traveling exhibition El Anatsui: When I Last Wrote to You About Africa, 2010-2013. Some other Nigerian artists whose works are well represented are David Dale, Bruce Onobrakpeya, Lara Ige-Jack, Adeola Balogun, Olu Amoda, and Lamidi Fakeye. A number of their works were commissioned by Shyllon, the founder and director of the Foundation. Commissioned works include Benchama Wrestler, 2001 (Fig. 15) by Adeola Balogun, Rose Garden, 2010 (Fig. 16) by David Dale, Open and Close, 2013 (Fig. 17) by Olu Amoda, Stallion Horse on the Move, 2013 (Fig. 18) by Luke Iyorah, and Oduduwa (The Creation Story), $2005-07$ (Fig. 19) by Lamidi Fakeye.

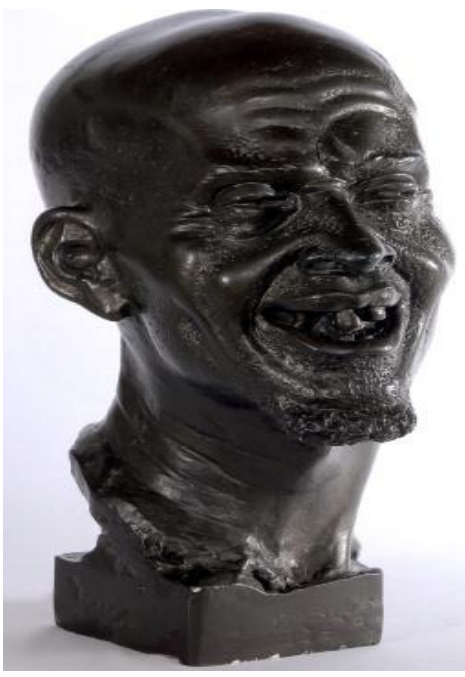

Figure 11. Abayomi Barber, Ali Maigoro, 1961. Plaster, $43 \mathrm{~cm}$. Photo: Courtesy of OYASAF

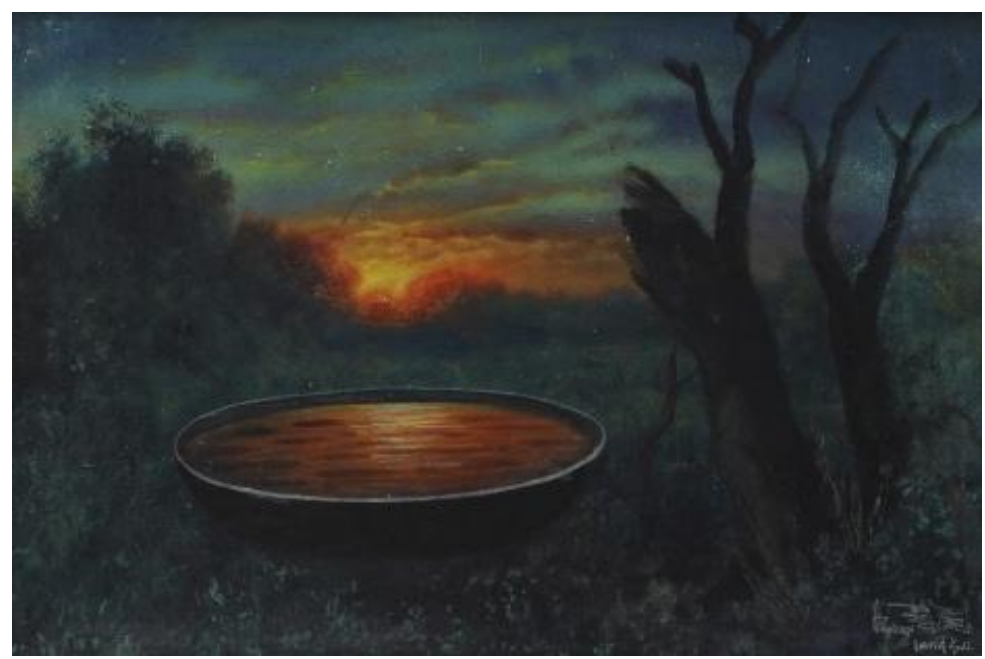

Figure 12. Abayomi Barber, In the Wilderness at Night, 1964. Oil on hardboard, $55 \mathrm{~cm}$ x $84 \mathrm{~cm}$. Photo: Courtesy of OYASAF 


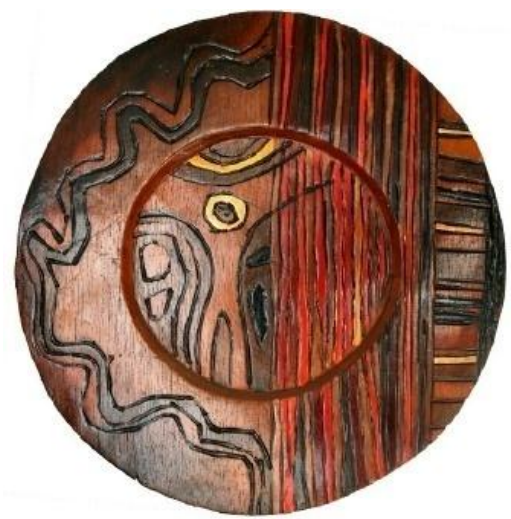

Figure 13. El Anatsui, Wisdom, 1974. Pyroengraving, paint, and lacquer on readymade wooden tray,

$40 \mathrm{~cm} \times 39.5 \mathrm{~cm} \times 2.4 \mathrm{~cm}$

Photo: Courtesy of OYASAF

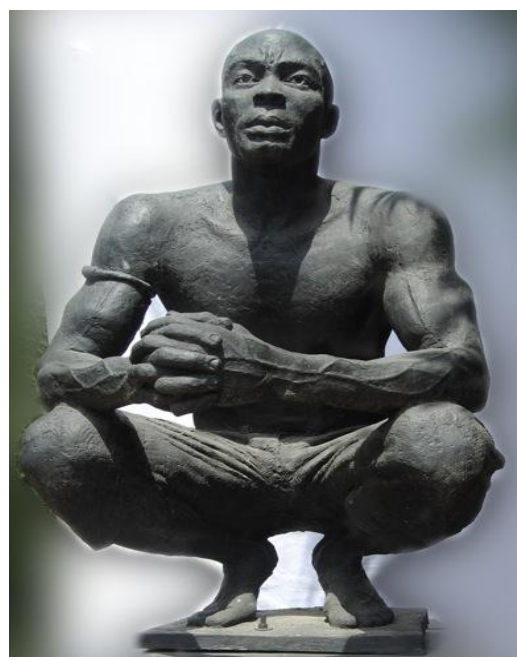

Figure 15. Adeola Balogun, Benchama Westler, 2001. Bronze, $160.9 \mathrm{~cm} \times 60 \mathrm{~cm} \times 16 \mathrm{~cm}$.

Photo: Courtesy of OYASAF

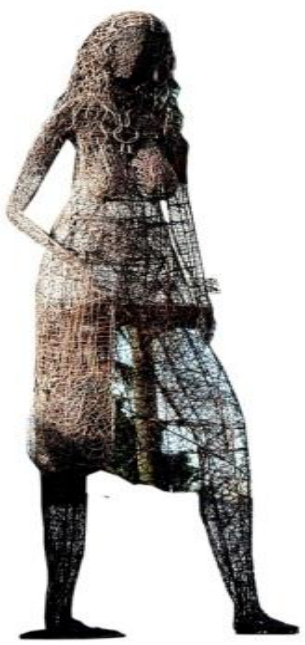

Figure 17. Olu Amoda, Open and Close,

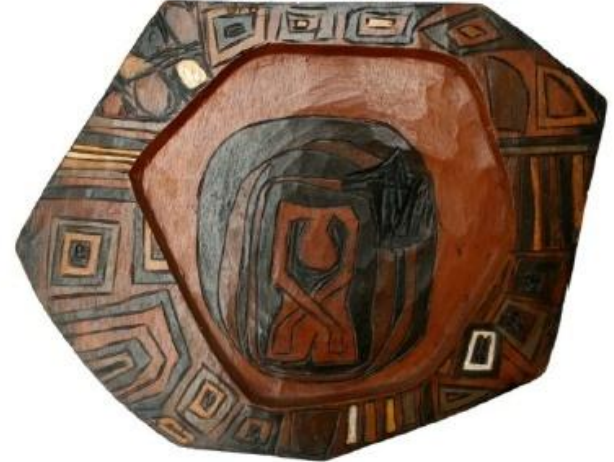

Figure 14. El Anatsui, Yaw Berko (Stand Up and Shout), 1973. Pyroengraving, paint, and lacquer on readymade wooden tray, $40 \mathrm{~cm}$ x $40 \mathrm{~cm}$ x $2.4 \mathrm{~cm}$. Photo: Courtesy of OYASAF

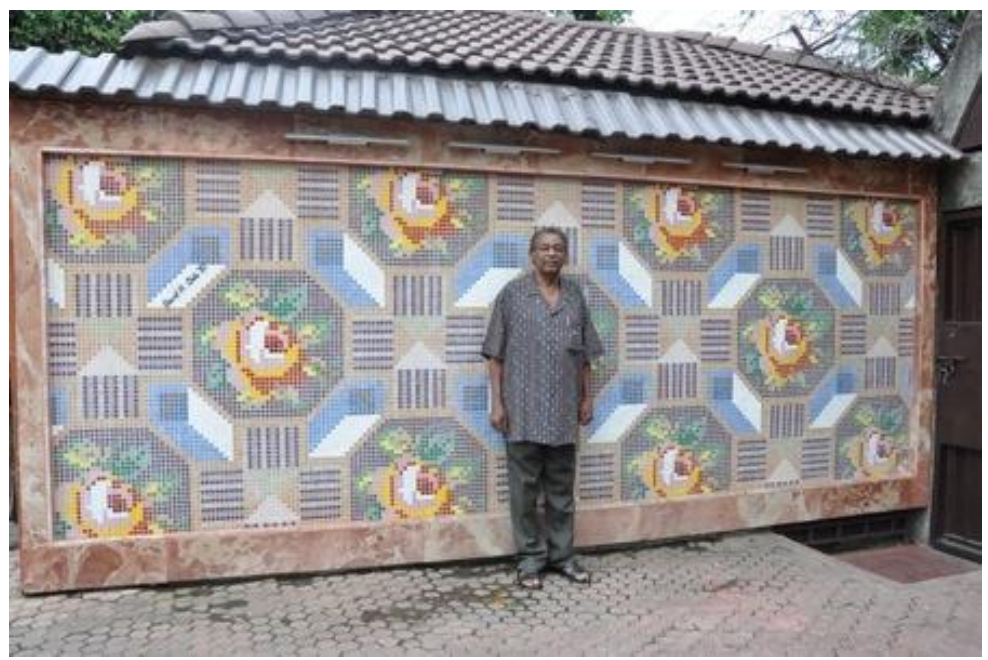

Figure 16. David Dale standing in front of his mosaic work titled Rose Garden, 2010 at OYASAF.

Photo: Tobenna Okwuosa

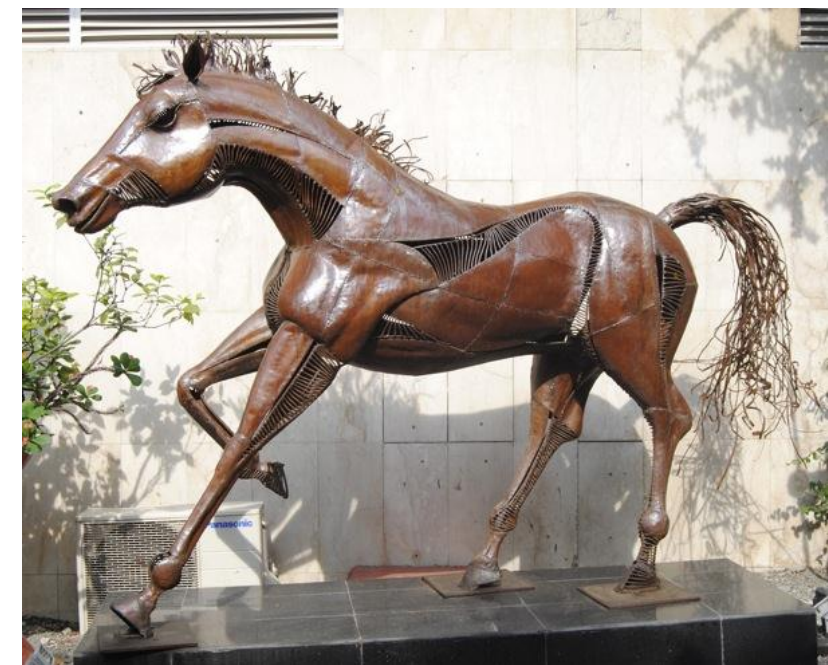

Figure 18. Luke Iyorah, Stallion Horse on the Move, 2013. 
"Art Patronage, Promotion, and Publication in Nigeria: A Focus on Omooba Yemisi Adedoyin...

2013. Metal rods and nails, $549 \mathrm{~cm}$.

Metal, $198 \mathrm{~cm}$ x $259 \mathrm{~cm}$. Photo: Courtesy of OYASAF

Photo: Courtesy of OYASAF

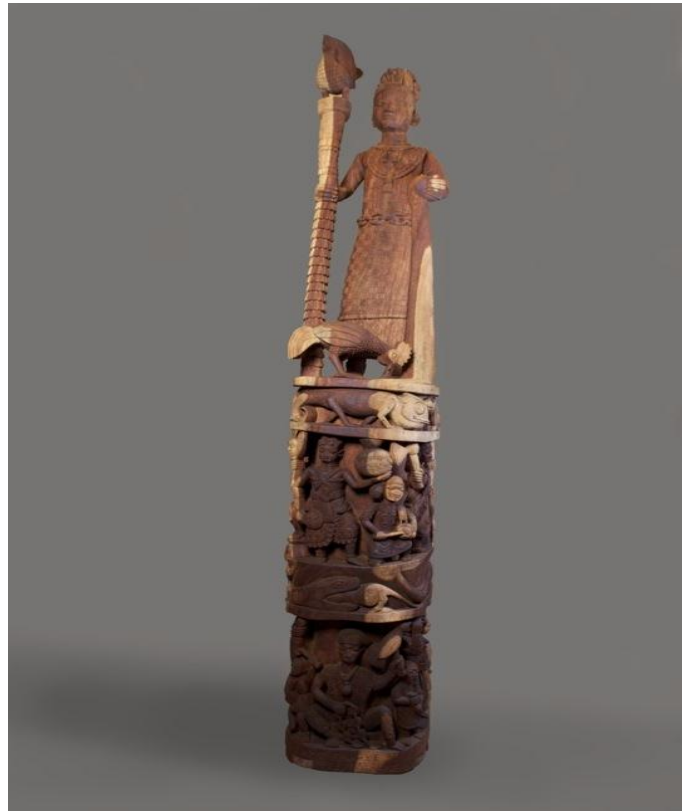

Figure 19. Lamidi Fakeye, Oduduwa (The Creation Story), 2005-07.

Wood, $390 \mathrm{~cm}$. Photo: Courtesy of OYASAF

\section{Art Promotion through Research and Publications}

One of the primary objectives of the Foundation is the promotion of modern and contemporary art and culture through research, publications, lectures and workshops. The Foundation has been mediating opportunities for exchanges in the arts by bringing to Nigeria art scholars, critics, graduate students and artists from the outside. Since 2010, thirteen persons from the US, Austria, Switzerland, and South Africa have been awarded an OYASAF Fellowship Grant. They are Janine Systma, Ian Bourland, Rachel Engmann, Andrea Bauer, Nomusa Makhubu, Kathleen Coates, Erica Agyeman, Amanda Hellman, Erin Rice, Amber Croyle Ekong, Kimberli Gant, Jessica Williams, and Victor Ekpuk. These individuals researched different aspects of Nigerian art and visual culture with the Foundation's collection serving as one of their primary resources. Their fellowships ended with a report on their work at the Foundation's Conference Centre.

To further generate knowledge on the contemporary Nigerian visual culture, the Foundation initiated a quarterly lecture series in 2012 that has given Nigerian intellectuals and scholars at home the opportunity to deal with such different issues as art education, art history, art practice and the business of art. The first lecture entitled "On African Art and Identity Blogging: A Historical Perspective" was delivered by Professor Frank Ugiomoh in 2012. The second lecture entitled "Contemporary Art in Nigeria: Contextual Navigation Through the Web of History" was given by Dr. Kunle Filani in January, 2013 and the third lecture entitled "The Price of Art and Its Implication on Art Practice in Nigeria" was given by Professor Jacob Jari in August, 2013. The fourth lecture entitled "Ladders of Progress or Shot in the Artists' Feet?" was delivered on January 29, 2014 by Dr. Ozioma Onuzulike. The lecture series was conceived to make Nigerian art historians, critics and scholars resident in the country, active participants in the research and theorising of Nigerian art and visual culture, which has been dominated by Western scholars and a few Nigerian scholars in the Diaspora.

Recently, OYASAF in collaboration with Chief Rasheed Gbadamosi's Grillo Pavilion, made a research grant available for scholars to research and resolve conflicting issues on "the formation, membership and program of the Zaria Art Society at the then College of Arts, Science and Technology (Ahmadu Bello University, Zaria)." With the conviction that scholarship and knowledge unfold ceaselessly in ways that either deconstruct or reconstruct dominant narratives, one cannot question the primacy of this research topic. It is pleasing to see an increase in the appreciation and recognition of such critical research and publications as 101 Nigerian Artists: A Celebration of Modern Nigerian Art, Chukwuemeka Bosah and George Edozie (2010); Making History: African Collectors and the Canon of African Art: The Femi Akinsanya African Art Collection, Sylvester Ogbechie (2011); Contemporary African Art: My Private Collection of Onyema Offoedu-Okeke, Okey Anueyiagu (2011); Contemporary Nigerian Art in Lagos Private Collections: New Trees in an Old Forest edited by Jess Castellote (2012); and Artists of Nigeria, Onyema Offoedu-Okeke (2012). 
OYASAF has launched a publication project based on conversations with the major living artists in its collection. Conversation with Lamidi Fakeye is the first in this series. It was published in 2013, reproducing 48 of Fakeye's wood carvings from the Foundation's collection in full-color. The book was coauthored by Prince (Engr.) Yemisi Adedoyin Shyllon and Dr. Ohioma Ifounu Pogoson. OYASAF prides itself on having the largest individual collection of artworks by Lamidi Fakeye. In 2009, the Foundation published a book on its holdings of Yoruba art entitled Yoruba Traditional Art: The Collection of Omooba Yemisi Adedoyin Shyllon Art Foundation (OYASAF) edited by Ohioma Ifounu Pogoson. OYASAF also presents works in its collection to a larger public through exhibitions like "Ancient Tones and Columns," an exhibition of traditional Nigerian art in the collections of Omooba Yemisi Adedoyin Shyllon Art Foundation (OYASAF) and The Omooba Oladele Odimayo Art Foundation (TOOAF) that held at the National Museum, Lagos, in 2008.

\section{Art Promotion through Competitions, Workshops and Exhibitions}

The Foundation uses art competitions, workshops and exhibitions to discover, develop and promote talents in the visual arts. In 2009, OYASAF organized a national competition in photography from which five winners emerged. The second edition the following year awarded prizes to the best ten entries; and an exhibition of the winning entries was held at the Aina Onabolu Exhibition Hall, National Gallery of Art (NGA), Lagos in 2010. Also in 2010, the Foundation cosponsored the "Children's Day Art Workshop" organized by Biodunomolayo Art Gallery, Lagos. The national photography competition after its second edition was replaced with a photographic documentation project that covers cultural events and festivals in Nigeria and beyond. The Foundation employs a dedicated photographer Ariyo Oguntimehin for this purpose. Some of the events and places he has documented are the Benin Kingdom's Igue festival, Onitsha's Ofala festival, the Igbo Ukwu festival (Fig. 20), Lagos' Eyo festival (Fig. 21), the Calabar carnival, the Lisabi festival, the Oyo Sango festival, the Badagry cultural festival, the Benin Republic's national voodoo festival in Ouidah ( (Fig. 22), and the Okpella Ancestral Festival (Olimi).

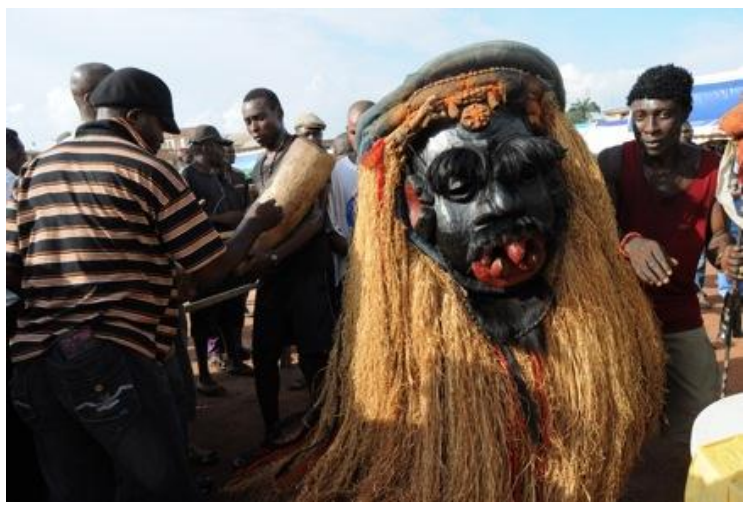

Figure 20. The Igbo Ukwu Festival, 2012, Digital Photography. Photo: Ariyo Oguntimehin Oguntimehin

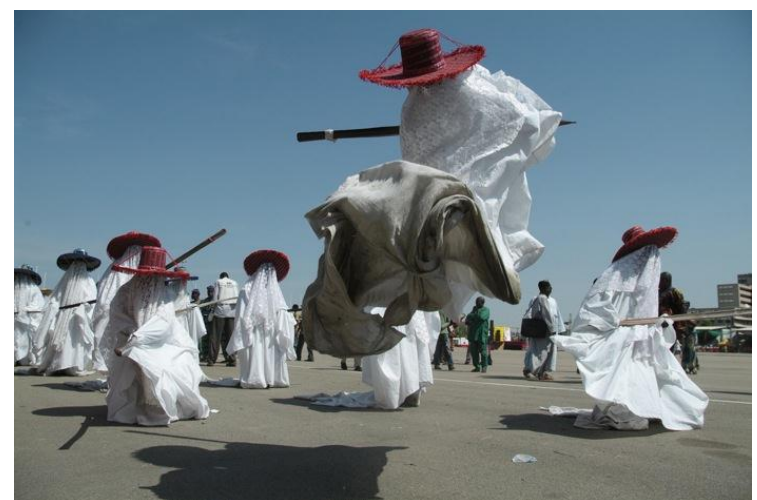

Figure 21. The Eyo Festival of Lagos. 2012, Digital Photography. Photo: Ariyo

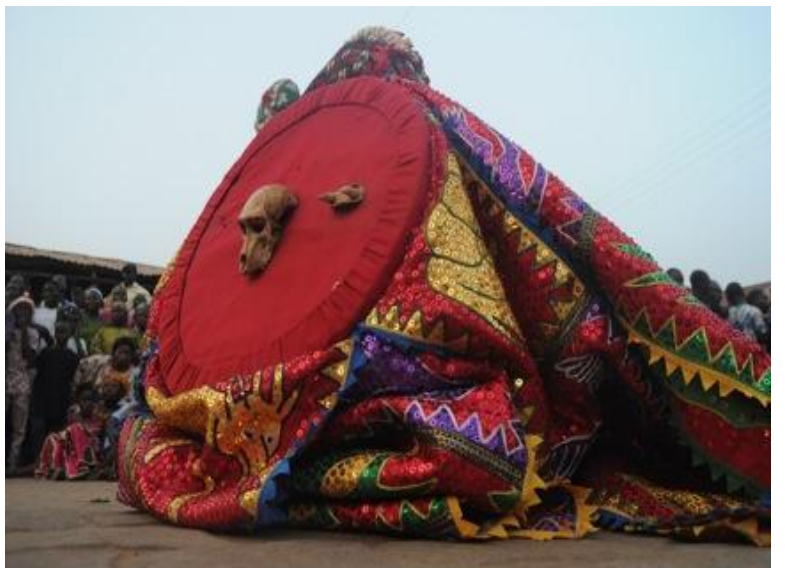

Figure 22. National Voodoo Festival (Ouidah) of Benin Republic, 2013, Digital Photography. Photo: Ariyo Oguntimehin 
Since 2011, OYASAF has also sponsored an annual visual arts workshop at the Department of Creative Arts, University of Lagos. The entrepreneurial workshop covers painting with pastel, watercolor, printmaking and ceramics. Kathleen Stafford, a printmaker and the wife of a former consul general of the American Consulate in Lagos, Nigeria, facilitated the printmaking session in 2011 (Fig. 23). The 2012 edition included photography and over 2,500 art students and professionals from different parts of the country have benefitted from these two programs. The third edition slated for 2013 was cancelled because of the nationwide strike by university lecturers that lasted for close to 6 months. In 2013, OYASAF sponsored a drawing competition among the secondary school students in Ile-Ife. The competition was organized by the art students of the Department of Fine and Applied Arts, Obafemi Awolowo University, Ile-Ife.

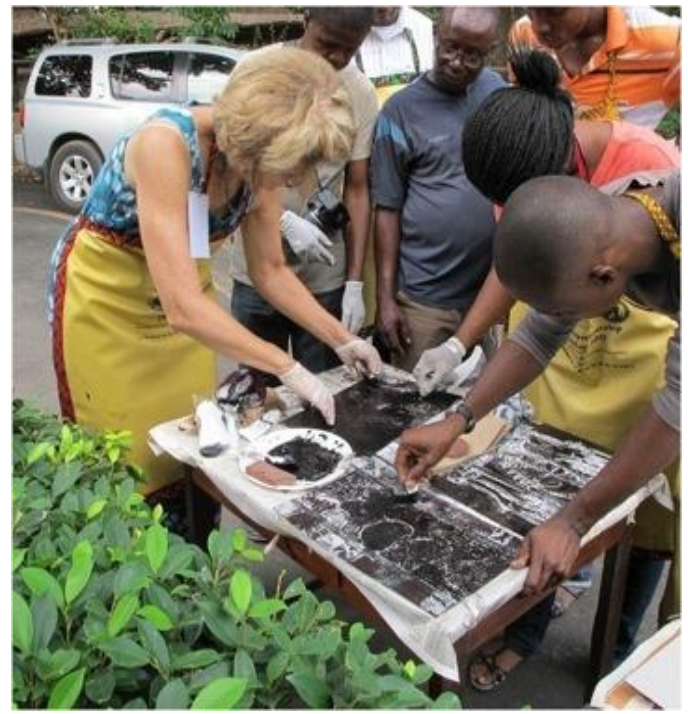

Figure 23. Kathleen Stafford facilitating the printmaking section at the OYASAF sponsored workshop at the University of Lagos in 2011. Photo: Courtesy of OYASAF

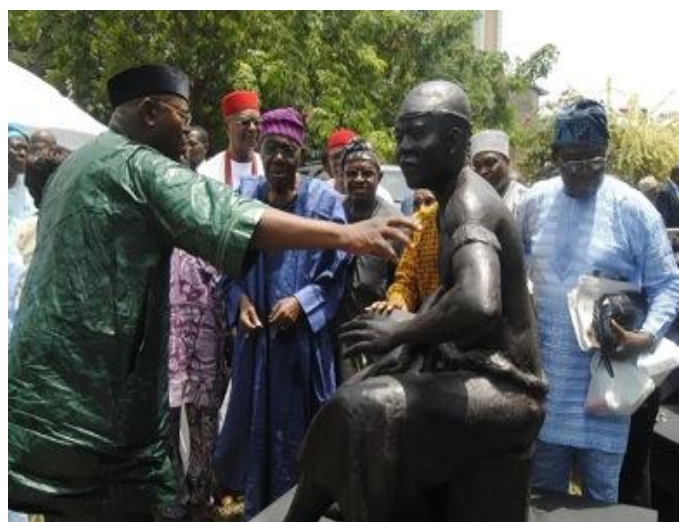

Figure 24. Prince (Engr.) Yemisi Shyllon talking about one of the eighteen sculptures donated to the Freedom Park, Lagos. Standing next to him is Chief Ernest Shonekan, a former Nigerian president and behind him is Igwe Nnaemeka Achebe, the Obi of Onitsha. Photo: Courtesy of OYASAF

\section{Philanthropic and Social Commitments}

Over the years, the Foundation has provided support for artists, national and international art institutions/associations, art departments, universities, and commercial galleries. Through the donation and installation of a sculpture to the University of Ibadan in 2009 and eighteen life-sized sculptures to the Freedom Park, Lagos (Fig. 24) in 2013, OYASAF has redefined and invested these public spaces with significant historical, cultural, and intellectual content. In 2009, the Foundation also facilitated the restoration of an oil landscape painted by Ben Enwonwu in 1952 in the Vice Chancellor's office at the University of Ibadan. The Foundation also upgraded the university's zoo and made it accessible to the disabled. The Foundation director's love for nature, animals and birds is a factor that gives the OYASAF's environmental space an Edenic look where artworks, birds, animals and humans coexist beautifully (Fig. 25). The Foundation also recently endowed a professorial chair in the Department of Fine Arts and Design at the University of Port Harcourt. In Nigeria 
where institutional and corporate sponsorship is sadly lacking, the philanthropic gestures of the Foundation have contributed in no small way to sustain many art activities and practices.

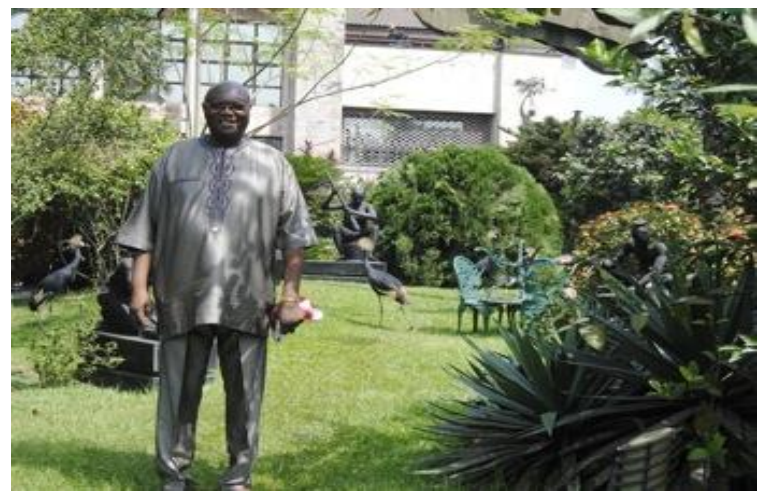

Figure 25. The Foundation's director in OYASAF's garden with three sculptures and two crowned crane in the background. Photo: Courtesy of OYASAF

\section{Conclusion}

OYASAF, a nonprofit and self-funded Foundation with strong commitment in the areas of art collecting, research, publication, and documentation of indigenous cultural festivals and practices, has made and continues to make significant contributions in the art and culture sectors of Nigeria. The Foundation has received many awards and honors and the founder was in 2013 awarded an honorary Doctor of Literature (D.Litt.) by the University of Port Harcourt, in recognition of his contributions. The Foundation's collection is a rich resource for studying historical and contemporary experiences through the eyes of the artists. Jess Castellote in Contemporary Nigerian Art in Lagos Private Collections: New Trees in an Old Forest notes that Nigerian collectors "collect works that are not only produced and appreciated locally, but which have their cultural roots well inserted into art discourses that more often than not differ substantially from those outside the continent, even if proffered by Africans in diaspora." 18

\section{Acknowledgments}

I wish to acknowledge the Arts Council of the African Studies Association (ACASA) for the 2014 Travel Award and the Omooba Yemisi Adedoyin Art Foundation (OYASAF) for the funding that enabled me to attend the 16th ACASA Triennial Symposium, Brooklyn Museum, Brooklyn, New York, March 19-23, 2014, where this paper was presented.

\section{References}

[1]. Sylvester Okwunodu Ogbechie, Ben Enwonwu: The Making of an African Modernist (Rochester, NY: University of Rochester Press, 2008), 46.

[2]. Christopher Nnonyelum Okeke, "Foreword" in Contemporary Textures: Multidimensionality in Nigerian Art, ed. Nkiru Nzegwu (Binghamton, NY: International Society for the Study of Africa, 1999), vii-ix.

[3]. Nkiru Nzegwu. "Introduction: Contemporary Nigerian Art: Euphonizing the Art Historical Voice" in Contemporary Textures: Multidimensionality in Nigerian Art, ed. Nkiru Nzegwu (Binghamton, NY: International Society for the Study of Africa, 1999), 1-39.

[4]. H.C. Ngumah, "Nigerian Art and Indigenous Patronage: The Way Forward" in Art in Contemporary Nigeria: Its Value andAppreciation, eds. Ola Oloidi and Simon Ikpakronyi (Abuja: National Gallery of Art, 2009), 34-41.

[5]. Nzegwu, "Introduction."

[6]. Frank Willet, African Art (New York, NY: Thames \& Hudson Inc, 2002), 64.

[7]. Walker, Roslyn A. Walker, "Palace Door (ilekun aafin)" in Selected Works from the Collection of the National Museum of African Art (Washington, D.C.: National Museum of African Art, Smithsonian Institution, 1999), 66.

[8]. Willet, African Art, 214.

[9]. Sylvester Okwunodu Ogbechie, Making History: African Collectors and the Canon of African Art: The Femi AkinsanyaAfrican Art Collection (Milan: 5 Continents Editions, 2011), 57.

[10]. Ibid., 71 .

[11]. Chika Okeke-Angulu, "The Challenges of the Modern: An Introduction," African Arts XXXIX, no. 1 (2006), 14-15.

[12]. Moyo Okedeji, Western Frontiers of African Art (Rochester, NY: University of Rochester Press, 2011 ), 1.

[13]. Ogbechie, Ben Enwonwu, 198.

[14]. Chinua Achebe, Things Fall Apart, (Ibadan: Heinemann Educational Book Ltd, 1958), 133-135.

[15]. Uche Okeke, "Extracts from Uche Okeke's Diary, 1957-1967" in The Art Society: A New Consciousness, eds. Chike Dike and Pat Oyelola (Lagos: National Gallery of Art, 1998), 270-89.

[16]. Freeborn Odiboh, "Creative Reformation of African Art Traditions: The Iconography of AbayomiBarber Art School," African Arts 42, no. 2 (2009) 76-83.

[17]. Ibid., 76-79.

[18]. Jess Castellote, "Collector and their Collections," in Contemporary Nigerian art in Lagos Private Collection: New Tree inan Old Forest, ed. Jess Castellote (Ibadan: Bookcraft, 2012) 57-79. 